\title{
ANALISIS PENGENDALIAN KUALITAS PROSES PRODUKSI PIE SUSU PADA PERUSAHAAN PIE SUSU BARONG DI KOTA DENPASAR
}

\author{
Ni Kadek Ratna Sari ${ }^{1}$ \\ Ni Ketut Purnawati ${ }^{2}$ \\ ${ }^{1,2}$ Fakultas Ekonomi dan Bisnis, Universitas Udayana, Bali, Indonesia \\ email:kadekratnasr@gmail.com
}

\begin{abstract}
ABSTRAK
Penelitian ini bertujuan untuk mengetahui apakah pengendalian kualitas yang dilakukan oleh Perusahaan Pie Susu Barong sudah optimal. Penelitian dilakukan di Perusahaan Pie Susu Barong di Kota Denpasar. Penelitian ini menggunakan metode penelitian deskriptif. Metode pengambilan sampel menggunakan random sampling. Data yang digunakan adalah jumlah kerusakan produk pada periode Oktober sampai dengan November 2017. Teknik analisis data menggunakan alat statistical quality control, yaitu diagram peta kendali $\mathrm{p}$ dan diagram sebab akibat serta analisis biaya kualitas. Hasil analisis biaya kualitas menunjukkan pengendalian kualitas belum optimal, karena tingkat kerusakan aktual 7884 biji pie susu total biaya kualitas (TQC) sebesar Rp 45.130 .510 yang terdiri dari biaya pengawasan kualitas (QCC) sebesar Rp 35.669.710 dan biaya jaminan kualitas (QAC) sebesar Rp 9.460.800 lebih besar dibandingkan tingkat kerusakan 15.308 biji pie susu dengan total biaya kualitas optimum (TQC*) sebesar Rp 36.740 .386 yang terdiri dari biaya pengawasan kualitas (QCC*) sebesar Rp 18.370.786 dan biaya jaminan kualitas (QAC*) sebesar Rp 18.369.600.
\end{abstract}

Kata Kunci: biaya kualitas, kualitas, pengendalian kualitas, statistical quality control

\begin{abstract}
The purpose of this study to determine whether the quality control performed by the Pie Susu Barong Company is optimal. The research was conducted at Pie Susu Barong Company in Denpasar City. This research uses descriptive research method. Sampling method using random sampling. The data used is the number of product damage in the period of October to November 2017. Data analysis techniques using statistical quality control tools, there are $p$ control diagram, cause and effect diagram, and cost quality analysis. The result of quality cost analysis shows that quality control is not optimal yet, because the actual damage level of 7884 pie of milk total quality cost (TQC) is Rp $45,130,510$ consisting of quality control (QCC) cost Rp 35.669.710 and quality assurance cost (QAC) amounting to Rp 9,460,800 is greater than the damage level of 15,308 milk pie seeds with total cost of optimum quality (TQC*) of Rp 36,740,386 consisting of quality control (QCC*) cost of $R p$ 18,370,786 and quality assurance cost (QAC*) of $R p$ $18,369,600$.
\end{abstract}

Keywords: quality, quality control, quality cost, statistical quality control 


\section{PENDAHULUAN}

Persaingan di dalam industri baik jasa maupun manufaktur tidak hanya dalam skala perusahaan dan sumber daya manusianya saja tetapi juga pada kualitas produk yang dihasilkan. Kualitas menjadi faktor penting dalam penentuan kepuasan yang diperoleh konsumen setelah membeli dan memakai produk, karena dengan kualitas produk yang baik akan dapat memenuhi keinginan dan kebutuhan konsumen sehingga sangat penting bagi perusahaan untuk tetap menjaga kualitas produk mereka agar dapat bersaing dengan perusahaan lain dalam mempertahankan kepuasan konsumen. Perusahaan yang tidak memiliki kualitas produk yang baik akan sulit bersaing dengan produk lainnya di pasar dan akan mengancam keuntungan serta keberlangsungan operasi perusahaan di masa mendatang, sedangkan perusahaan yang memiliki kualitas produk yang baik akan mampu bersaing dengan produk lainnya dan akan tetap eksis dengan profitabilitas yang meningkat di masa mendatang (Putra, 2016). Permasalahan yang sering timbul pada proses produksi dan dapat memengaruhi kualitas adalah adanya produk rusak, sehingga memerlukan langkah atau usaha untuk memecahkan masalah tersebut agar kualitas produk dapat terjaga dengan baik (Hariyanto, 2017).

Perusahaan perlu melakukan pengendalian kualitas terhadap proses produksi untuk tetap menjaga kualitas produk yang dihasilkan. Pengendalian kualitas menjadi salah satu fungsi yang penting dari suatu perusahaan, untuk itu kualitas produk harus ditangani oleh bagian pengendalian kualitas dalam perusahaan mulai dari pengendalian bahan baku, pengendalian kualitas proses produksi sampai 
Ni Kadek Ratna Sari, Analisis Pengendalian Kualitas Proses Produksi Pie Susu...

produk siap untuk dipasarkan (Assauri, 2004:211). Pengendalian kualitas perlu dilakukan perusahaan sebagai upaya untuk mempertahankan kualitas produknya agar sesuai dengan standar yang ditetapkan oleh perusahaan (Prihatiningtias, 2014).

Pengendalian kualitas dapat dilakukan secara statistik atau disebut dengan pengendalian kualitas statistik (Statistical Quality Control / SQC). Pengendalian kualitas statistik adalah teknologi yang banyak digunakan di industri manufaktur untuk meningkatkan kualitas produk dan produktivitas pekerja (Oguntunde, 2015). Penelitian yang dilakukan Banker, et al. (2014) pada Apurvi Industri yang menemukan bahwa penerapan pengendalian kualitas statistik dapat meningkatkan produktivitas. Darsono (2013) dan Mostafaeipour, et al. (2012) menyatakan bahwa aktivitas pengendalian kualitas secara statistik dapat membantu dalam menekan jumlah produk yang rusak dan membantu proses produksi menjadi lebih baik. Pengendalian kualitas statistik berarti melakukan pengendalian dengan metode statistik mulai dari bahan baku, selama proses produksi berlangsung sampai pada produk akhir dan selanjutnya disesuaikan dengan standar yang telah ditetapkan sehingga dapat menghasilkan produk yang berkualitas dan tidak cacat (Yuliasih, 2014).

Penggunaan pengendalian kualitas secara statistik telah dilakukan oleh beberapa peneliti sebelumnya untuk melihat sistem pengendalian kualitas yang dilakukan di beberapa perusahaan apakah sudah dalam kendali dengan melihat tingkat kerusakan produk yang terjadi. Penelitian empiris Elmas (2017) menyatakan bahwa pengendalian kualitas di Toko Roti Bakery sudah baik karena 
jumlah produk gagal masih dalam batas wajar yaitu terletak antara batas atas (UCL) dan batas bawah (LCL). Analisis diagram sebab akibat menunjukkan bahwa faktor utama penyebab terjadinya kegagalan produk disebabkan karena kelalaian manusia atau faktor sumber daya manusianya. Penelitian Yuliyarto, dkk. (2014) menyatakan bahwa proses pelaksanaan quality control produksi susu sapi di CV. Cita Nasional menunjukkan proses berada dalam keadaan tidak terkendali (out of control) atau masih mengalami penyimpangan, hal tersebut dikarenakan adanya titik berfluktuasi sangat tinggi dan tidak beraturan, serta banyak terdapat titik yang keluar dari batas kendali. Melalui analisis alat diagram sebab akibat, kerusakan yang terjadi dalam proses produksi disebabkan dari faktor manusia, metode, material, mesin dan lingkungan kerja.

Haslindah (2013) menyatakan bahwa dalam peta kontrol P pada grafik produk minuman rumput laut berada diluar batas kontrol, hal ini menunjukkan produksi berlangsung tidak menurut spesifikasi yang telah ditentukan. Penelitian Ayu Ningsih, dkk. (2016) menyatakan bahwa kerusakan dodol salak di CV. Duta Gunung Salak berada di luar batas kendali, artinya dalam produksinya masih terdapat penyimpangan yang terjadi. Penelitian Mahesh dan Prabhuswamy (2010) yang menyatakan bahwa produksi produk sabun berada diluar kendali, yaitu sekitar 23-28\% sabun yang diproduksi berada di luar batas spesifikasi. Ini menunjukkan bahwa variabilitas dalam prosesnya sangat tinggi.

Menjaga kualitas produk yang dihasilkan juga dipengaruhi oleh biaya kualitas yang dikeluarkan oleh perusahaan. Biaya kualitas menjadi salah satu alat ukur yang dapat dipakai perusahaan untuk mengukur keberhasilan program 
Ni Kadek Ratna Sari, Analisis Pengendalian Kualitas Proses Produksi Pie Susu...

perbaikan kualitas. Ransun (2016) menyatakan bahwa semakin baik penentuan penggunaan biaya kualitas maka akan meningkatkan kualitas dari suatu produk yang akan dihasilkan.

Perusahaan Pie Susu Barong merupakan salah satu usaha pie susu di Bali tepatnya di Kota Denpasar. Produk yang dihasilkan yaitu pie susu rasa original dengan merk barong dan legong dengan ukuran $5 \mathrm{~cm}$. Pie Susu Barong memiliki pekerja sebanyak kurang lebih 22 orang. Proses produksi dimulai dari pukul 07.00 WITA sampai dengan 18.00 WITA. Proses produksi pie susu rata - rata bersifat homogen yaitu prosesnya dimulai dari pembuatan adonan, pencetakan, pengovenan, dan terakhir adalah proses packaging.

Berdasarkan hasil wawancara dan observasi yang dilakukan bahwa Perusahaan Pie Susu Barong telah melakukan pengendalian kualitas setiap harinya, namun masih ditemukan adanya produk rusak yang dihasilkan oleh perusahaan tersebut. Kriteria kerusakan produk pie susu seperti bentuk yang remuk, warna gosong, dan ukuran yang tidak sesuai, apabila produk rusak terus terjadi akan dapat memengaruhi keuntungan yang diperoleh. Produk rusak berpengaruh pada keuntungan yang diperoleh perusahaan dikarenakan biaya dikeluarkan akan meningkat (Elmas, 2017). Produk rusak dapat memengaruhi keuntungan karena dalam produksinya produk yang rusak telah memakan biaya produksi dan tidak dapat diperbaiki kembali. Artinya, apabila produk rusak tersebut jumlahnya terus meningkat maka dapat berdampak pada peningkatan harga pokok produksi per unit barang yang dihasilkan, sehingga dapat mengurangi 
keuntungan yang diperoleh oleh perusahaan serta berdampak buruk pada persaingan di dunia usaha (Wahyuni, 2016).

Adanya hasil produksi produk rusak menunjukkan bahwa pengendalian kualitas produk yang dilakukan di Perusahaan Pie Susu Barong belum maksimal dan sulit menentukan batas standar kerusakan karen tidak ada data kerusakan yang dibuat. Upaya pengendalian kualitas lebih lanjut perlu dilakukan oleh Perusahaan Pie Susu Barong untuk menentukan batas kerusakan. Upaya pengendalian kualitas dapat dilakukan dengan cara mengeluarkan biaya - biaya kualitas dan pengendalian kualitas secara statistik. Penggunaan alat bantu statistik dapat membantu menentukan standar kerusakan serta mencari factor - faktor penyebab kerusakan, sehingga nantinya perusahaan dapat menekan tingkat kerusakan dan berproduksi secara lebih optimal. Pengurangan produk yang rusak secara tidak langsung meningkatkan produktivitas dan profitabilitas organisasi (Bambharoliya, 2015).

Adapun permasalahan yang terjadi adalah apakah sistem pengendalian kualitas yang dilakukan oleh Pie Susu Barong sudah optimal atau belum, hal ini perlu dilakukan analisis lebih lanjut, sehingga untuk tujuan dari penelitian ini adalah untuk mengetahui apakah sistem pengendalian kualitas yang dilakukan oleh Pie Susu Barong sudah optimal. Penelitian diharapakan dapat memberikan manfaat yang dapat dirasakan oleh penulis saja, melainkan memberikan manfaat terhadap elemen atau pihak-pihak yang terkait dalam penelitian ini baik secara langsung maupun tidak langsung. Manfaat teoritis yang diharapkan dalam penelitian adalah dapat memberikan pengetahuan tentang bagaimana 
Ni Kadek Ratna Sari, Analisis Pengendalian Kualitas Proses Produksi Pie Susu...

pengendalian kualitas dengan menggunakan alat bantu statistik dapat bermanfaat untuk mengendalikan tingkat kerusakan produk di Perusahaan Pie Susu Barong. Secara praktis penilitian ini dapat memberikan manfaat bagi perusahaan Pie Susu Barong sebagai bahan masukan yang berguna terutama dalam menentukan strategi pengendalian kualitas yang dilakukan oleh perusahaan di masa yang akan datang sebagai upaya peningkatan kualitas produksi, serta memberikan arahan dan tambahan referensi bagi kalangan akademisi untuk keperluan studi dan penelitian selanjutnya mengenai topik permasalahan yang sama.

\section{METODE PENELITIAN}

Desain penelitian yang digunakan dalam penelitian ini adalah pendekatan kuantitatif yang berbentuk deskriptif, yaitu penelitian yang dilakukan dengan cara menjelaskan dan menguraikan mengenai pelaksanaan pengendalian kualitas produk pie susu, faktor-faktor apa saja yang menyebabkan kerusakan pada produk yang diproduksi, serta solusi dalam mengatasi kendala-kendala pengendalian kualitas produk pie susu pada Perusahaan Pie Susu Barong.

Penelitian dilakukan di Pabrik Pie Susu Barong yang berada di Jalan Nangka, Gg. Nuri I, Denpasar, Bali. Penentuan lokasi penelitian didasarkan atas beberapa pertimbangan antara lain karena letaknya yang begitu strategis dan mudah dijangkau serta adanya keterbatasan biaya, waktu, tenaga yang dimiliki. Penelitian dilaksanakan selama satu bulan atau 25 hari kerja yaitu pada bulan Oktober 2017 sampai dengan bulan bulan November 2017.

Objek penelitian dalam penelitian ini adalah pengendalian kualitas produksi produk Pie Susu pada Perusahaan Pie Susu Barong di Denpasar. Variabel yang 
diidentifikasi dalam penelitian ini adalah: 1) Standar kualitas produk; 2) Jumlah Produksi; 3) Jumlah Produk Rusak dalam Proses Produksi; dan 4) Biaya Kualitas Populasi dalam penelitian ini adalah hasil produksi per hari pie susu dengan kapasitas produksi per harinya sebanyak kurang lebih 10.800 sampai dengan 11.000 bungkus, sehingga jumlah populasi kurang lebih 272.500 bungkus selama 25 hari kerja (1 bulan ).

Penarikan sampel produk pie susu rasa original yang akan diperiksa dilakukan secara random sampling yaitu sampel yang diambil sebanyak 550 biji pie susu. Pengambilan sampel 550 produk pie susu dilakukan karena keterbatasan waktu karyawan yang mendampingi pada saat penelitian dan jumlah populasi yang sangat banyak, dengan demikian jumlah sampel pie susu untuk satu bulan (25 hari kerja) sebanyak kurang lebih 13.750 biji pie susu.

Pemberi data atau informasi dalam penelitian ini dilakukan menggunakan metode purposive sample yaitu pemilihan pemberi informasi yang dilakukan secara sengaja berdasarkan tugas dan tanggung jawab dalam perusahaan. Pemberi informasi dalam penelitian ini sebanyak tiga orang yang terdiri dari pemilik perusahaan, satu orang tenaga pengawas (supervisor) dan satu orang karyawan produksi. Metode pengumpulan data yang digunakan dalam penelitian ini adalah sebagai berikut observasi dan wawancara.

Teknik analisis data dilakukan dengan menggunakan teknik pengendalian kualitas secara statistik dengan langkah-langkahnya adalah sebagai berikut: 1) Mengumpulkan data produksi dan produk rusak (check sheet); 2) Membuat Peta 
Ni Kadek Ratna Sari, Analisis Pengendalian Kualitas Proses Produksi Pie Susu...

Kendali P (P- chart); 3) Analisis Biaya Kualitas; dan 4) Membuat rekomendasi/ usulan perbaikan kualitas.

Penelitian ini menggunakan peta kendali p dengan batas kendali 3 sigma, karena hal ini sangat bagus dalam mendemonstrasikan proses saat data bervariasi (Patil, et al., 2015). Langkah dalam membuat peta kendali p sebagai berikut:

Menghitung persentase kerusakan

$$
P \quad=\frac{n p}{n}
$$

Keterangan :

$n p$ : jumlah gagal dalam sub grup

$n$ : jumlah yang diperiksa dalam sub grup hari ke - i

Menghitung garis pusat/Central Line (CL)

$$
\mathrm{CL}=\frac{\sum \underline{n p}}{\sum n}
$$

Keterangan :

$\sum n p:$ jumlah total yang rusak

$\sum n:$ jumlah total yang diperiksa

Menghitung batas kendali atas atau Upper Control Limit (UCL)

$$
\mathrm{UCL}=P+3 \sqrt{\mathrm{P}(1-\mathrm{P})}
$$

Keterangan :

$p:$ rata-rata ketidak sesuaian produk

$n:$ jumlah sampel yang diperiksa

Menghitung batas kendali bawah atau Lower Control Limit (LCL)

$$
\mathrm{LCL}=P-3 \sqrt{\mathrm{P}(1-\mathrm{P})}
$$

Keterangan : 
$p:$ rata-rata ketidaksesuaian produk

$n:$ jumlah sampel yang diperiksa

Langkah selanjutnya adalah mencari faktor penyebab kerusakan produk dengan diagram sebab - akibat (fishbone diagram). Jenis - jenis kerusakan yang terjadi selanjutnya akan dicari faktor - faktor penyebab kerusakannya. Begitu penyebabnya teridentifikasi, langkah selanjutnya dan terakhir adalah menghasilkan solusi untuk mencegah dan memperbaiki masalah ini (Jha, 2013).

Analisis biaya kualitas (quality cost) yang terdiri atas biaya pengawasan kualitas (QCC), biaya jaminan kualitas (QAC), total biaya kualitas (TQC), dan q* (jumlah kerusakan) dengan rumus sebagai berikut (Sutrisno, 2012).

Biaya pengawasan kualitas (quality control cost)

$$
\mathrm{QCC}=\frac{\text { R.o }}{\mathrm{q}}
$$

Keterangan:

QCC = total biaya pengawasan kualitas

$\mathrm{R}=$ jumlah produksi selama periode

$\mathrm{o}$ = biaya pengetesan

$\mathrm{q}=$ jumlah pie susu rusak selama periode

Biaya jaminan kualitas (quality assurance cost)

$$
\mathrm{QAC}=\mathrm{c} \cdot \mathrm{q}
$$

Keterangan:

$\mathrm{QAC}=$ total biaya jaminan kualitas

$\mathrm{c}=$ biaya jaminan kualitas

$q=$ jumlah produk rusak selama periode 
Ni Kadek Ratna Sari, Analisis Pengendalian Kualitas Proses Produksi Pie Susu...

Biaya atas kualitas (total quality cost)

$$
\mathrm{TQC}=\mathrm{QCC}+\mathrm{QAC}
$$

Keterangan:

TQC = total biaya atas kualitas

QCC = total biaya pengawasan kualitas

QAC = total biaya jaminan kualitas

Hubungan antar biaya kualitas dengan tingkat kerusakan produk dapat digambarkan ke dalam sebuah grafik berikut ini.

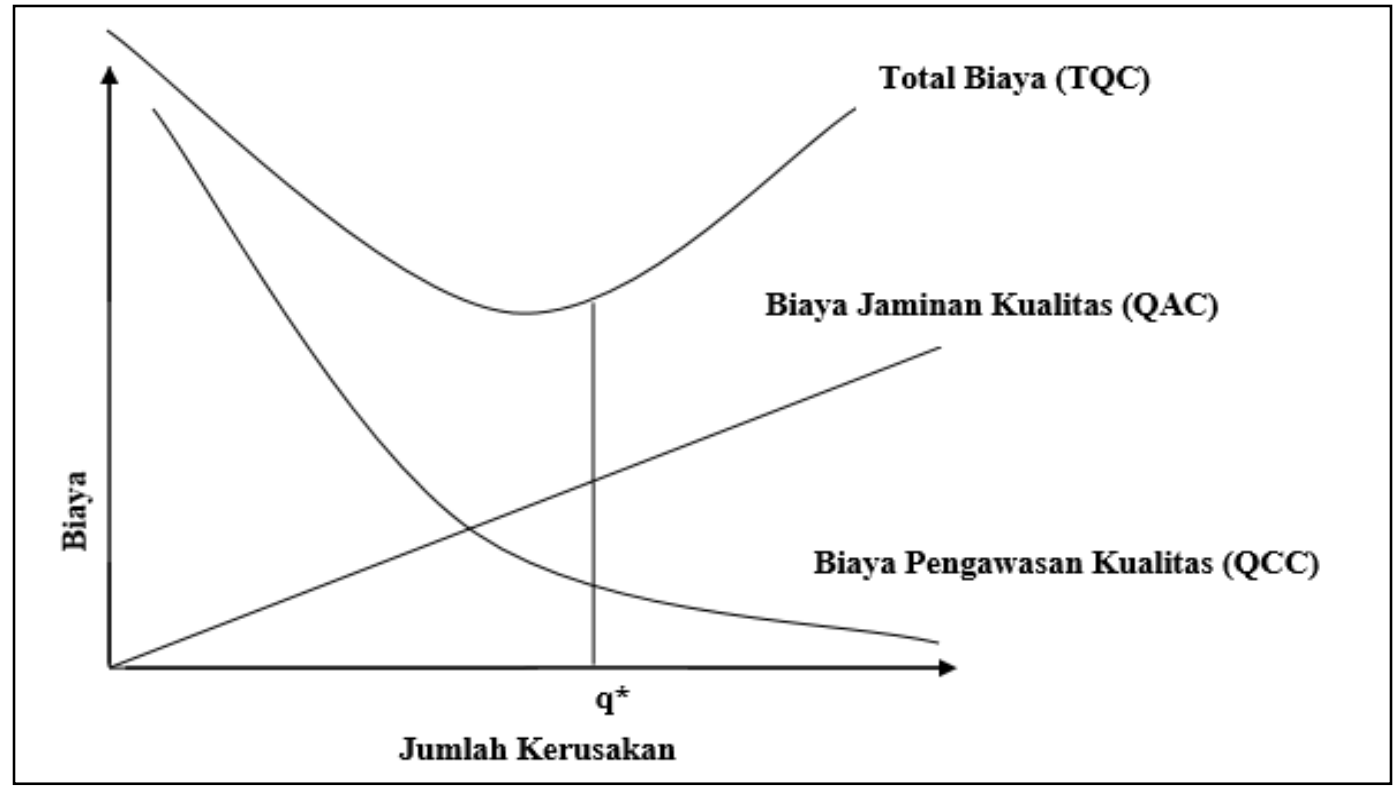

Gambar 1. Grafik Total Biaya Kualitas

\section{HASIL DAN PEMBAHASAN}

Berdasarkan hasil pengumpulan data melalui observasi di Perusahaan Pie Susu Barong, maka diperoleh catatan berupa jumlah produksi dan jumlah kerusakan produk yang terjadi selama satu bulan atau 25 hari kerja, adalah sebagai berikut: 
Tabel 1.

Jenis dan Jumlah Kerusakan Produk Pie Susu pada Perusahaan Pie Susu Barong pada Bulan Oktober s.d November 2017

\begin{tabular}{|c|c|c|c|c|c|c|}
\hline \multirow[b]{2}{*}{ Hari Ke- } & \multirow[b]{2}{*}{ Sampel } & \multicolumn{3}{|c|}{ Jenis Kerusakan } & \multirow[b]{2}{*}{$\begin{array}{c}\text { Jumlah } \\
\text { Kerusakan }\end{array}$} & \multirow[b]{2}{*}{$\begin{array}{c}\text { Persentase } \\
\text { Kerusakan } \\
\quad(\%)\end{array}$} \\
\hline & & $\begin{array}{l}\text { Bentuk } \\
\text { Remuk }\end{array}$ & $\begin{array}{l}\text { Warna } \\
\text { Gosong }\end{array}$ & $\begin{array}{c}\text { Ukuran } \\
\text { Tidak } \\
\text { Sesuai }\end{array}$ & & \\
\hline 1 & 550 & 8 & 10 & 4 & 22 & $4 \%$ \\
\hline 2 & 550 & 5 & 6 & 3 & 14 & $3 \%$ \\
\hline 3 & 550 & 15 & 15 & 10 & 40 & $7 \%$ \\
\hline 4 & 550 & 9 & 12 & 2 & 23 & $4 \%$ \\
\hline 5 & 550 & 10 & 10 & 9 & 29 & $5 \%$ \\
\hline 6 & 550 & 19 & 18 & 3 & 40 & $7 \%$ \\
\hline 7 & 550 & 8 & 4 & 4 & 16 & $3 \%$ \\
\hline 8 & 550 & 9 & 8 & 9 & 26 & $5 \%$ \\
\hline 9 & 550 & 6 & 8 & 2 & 16 & $3 \%$ \\
\hline 10 & 550 & 12 & 10 & - & 22 & $4 \%$ \\
\hline 11 & 550 & 8 & 10 & 2 & 20 & $4 \%$ \\
\hline 12 & 550 & 12 & 14 & 3 & 29 & $5 \%$ \\
\hline 13 & 550 & 12 & 13 & - & 25 & $5 \%$ \\
\hline 14 & 550 & 20 & 10 & 2 & 32 & $6 \%$ \\
\hline 15 & 550 & 8 & 14 & 8 & 30 & $5 \%$ \\
\hline 16 & 550 & 10 & 11 & 6 & 27 & $5 \%$ \\
\hline 17 & 550 & 16 & 6 & - & 22 & $4 \%$ \\
\hline 18 & 550 & 11 & 10 & 3 & 24 & $4 \%$ \\
\hline 19 & 550 & 12 & 17 & - & 29 & $5 \%$ \\
\hline 20 & 550 & 11 & 16 & 4 & 31 & $6 \%$ \\
\hline 21 & 550 & 10 & 17 & 3 & 30 & $5 \%$ \\
\hline 22 & 550 & 5 & 12 & - & 17 & $3 \%$ \\
\hline 23 & 550 & 18 & 14 & - & 32 & $6 \%$ \\
\hline 24 & 550 & 17 & 10 & 2 & 29 & $5 \%$ \\
\hline 25 & 550 & 10 & 19 & 3 & 32 & $6 \%$ \\
\hline Total & 13.750 & 281 & 294 & 82 & 657 & $119 \%$ \\
\hline Rata - rata & 550 & 11,24 & 11,76 & 3,28 & 26,28 & $4.8 \%$ \\
\hline
\end{tabular}

Sumber: Data Observasi, 2017

Berdasarkan data pada Tabel 1. dapat diketahui bahwa dari 550 sampel pie susu yang diambil per harinya atau sebanyak 13.750 biji pie susu selama satu bulan terdapat 657 biji pie susu yang mengalami kerusakan dengan rata - rata kerusakan per harinya sebesar 26 biji pie susu. Terdapat tiga kategori kerusakan 
Ni Kadek Ratna Sari, Analisis Pengendalian Kualitas Proses Produksi Pie Susu...

yang terjadi yaitu rusak karena bentuk remuk, warna gosong dan ukuran yang tidak sesuai. Dari ketiga kategori tersebut, kerusakan produk yang paling tinggi adalah dikarenakan warna gosong yaitu sebanyak 294 biji pie susu, sedangkan kerusakan sisanya disebabkan karena bentuk remuk sebesar 281 biji pie susu dan rusak karena ukuran tidak sesuai sebesar 82 biji pie susu. Jumlah kerusakan produk per hari yang paling tinggi selama bulan Oktober - November terjadi di hari ke 3 dan hari ke 6, yaitu sebanyak 40 biji pie susu, sedangkan jumlah kerusakan yang paling rendah terjadi pada hari ke 2 dan 9 yaitu sebanyak 14 biji pie susu.

Tahap selanjutnya adalah membuat peta kendali p. Berdasarkan table 4.3 maka dapat diketahui batas kendali menggunakan peta kendali $\mathrm{p}$ selama bulan Oktober s.d November 2017, dapat dilihat pada Tabel 2.

Tabel 2.

Batas - batas Kendali Kerusakan Pie Susu pada Bulan Oktober s.d November Tahun 2017

\begin{tabular}{lcc}
\hline \multicolumn{1}{c}{ Uraian } & Jumlah \\
\hline Jumlah Sampel Produksi (biji) & & 13.750 \\
Jumlah Kerusakan Produk (biji) & CL & 657 \\
& UCL & 0.048 \\
Batas Kendali & LCL & 0.075 \\
& & 0.021 \\
\hline
\end{tabular}

Sumber: Data diolah, 2017

Langkah selanjutnya adalah membuat diagram kontrol atau peta kendali yang disajikan sebagai berikut: 


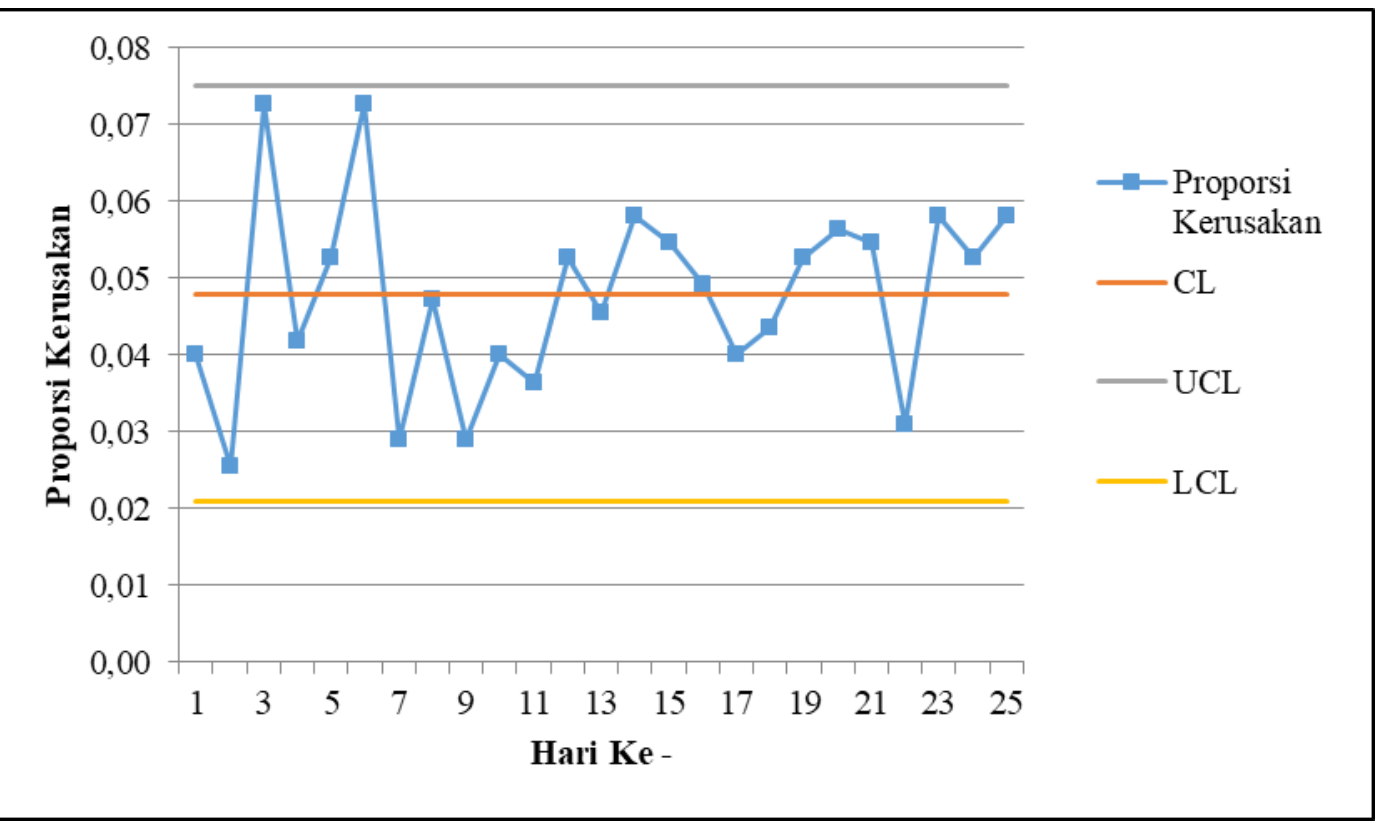

Gambar 2. p-chart Kerusakan Produk Pie Susu Bulan Oktober s.d November 2017

Sumber: Data diolah, 2017

Berdasarkan Gambar 2. dapat dilihat bahwa tidak ada titik yang berada diluar batas kendali (UCL dan LCL). Seluruh titik yang berjumlah sebanyak 25 titik berada dalam batas kendali, maka dapat dikatakan bahwa pengendalian kualitas proses produksi pie susu masih dalam kendali, namun dari ke 25 titik dapat dilihat bahwa ada tiga titik yang hampir melewati batas kendali, yaitu titik yang berada di hari ke- 2, 3 dan 6, sehingga titik - titik tersebut terlihat berfluktuasi dan tidak beraturan. Artinya, hal tersebut menandakan bahwa pengendalian kualitas untuk produk pie susu masih mengalami penyimpangan. Oleh sebab itu, masih perlu dilakukan analisis lebih lanjut untuk mengetahui penyebab penyimpangan ini terjadi dengan menggunakan diagram sebab-akibat (fishbone diagram).

Analisis diagram tulang ikan merupakan alat untuk menganalisa proses bisnis dan efektivitasnya (Bose, 2012). Penyebab kerusakan produk pie susu di 
Ni Kadek Ratna Sari, Analisis Pengendalian Kualitas Proses Produksi Pie Susu...

Perusahaan Pie Susu Barong adalah disebabkan oleh faktor man, machine, method, dan environment. Berikut ini adalah penggunaan diagram sebab - akibat dalam menganalisis penyebab ketiga jenis kerusakan produk yang terjadi di Perusahaan Pie Susu Barong. Kerusakan pertama yaitu bentuk remuk digambarkan dalam diagram sebab akibat adalah sebagai berikut.

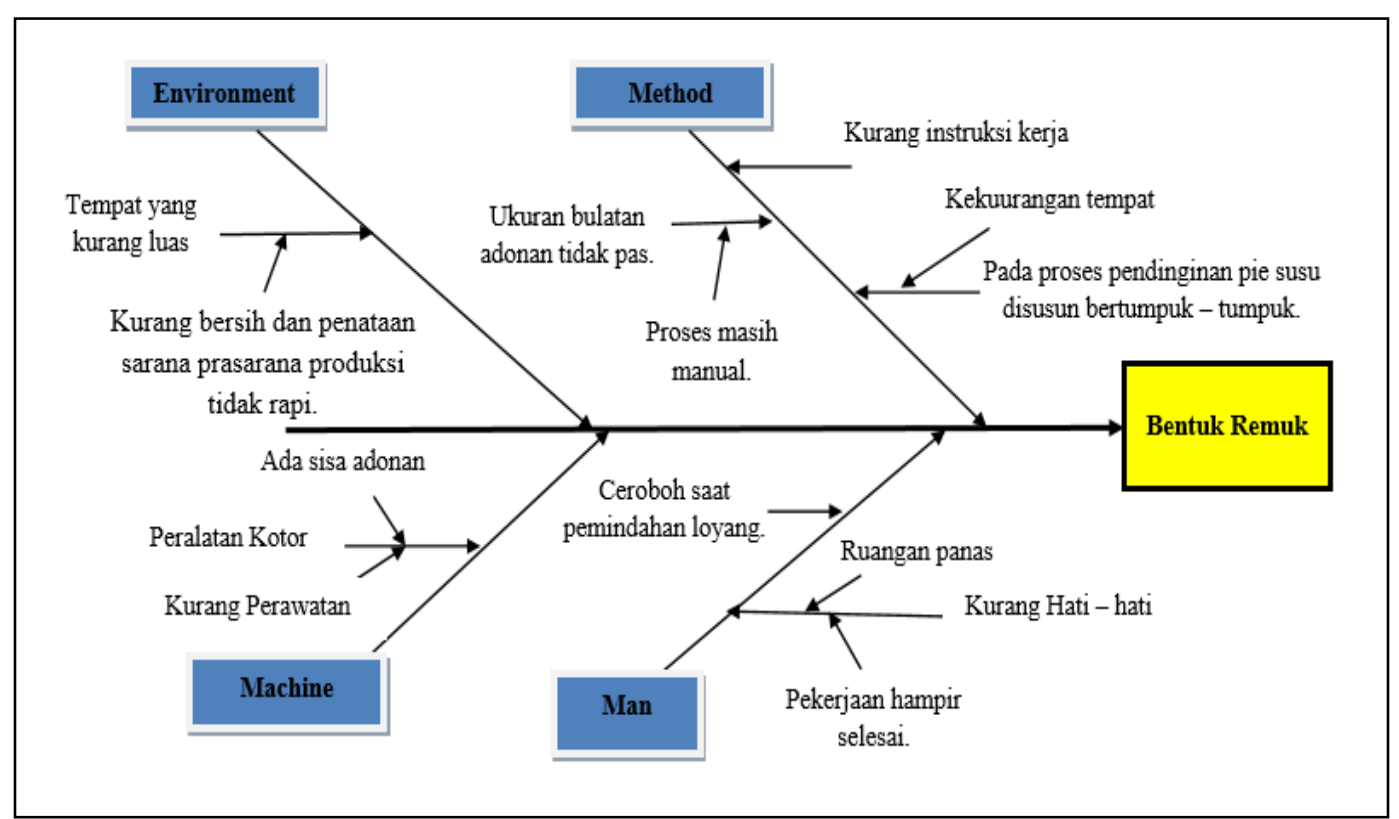

Gambar 3. Fishbone Diagram Produk Rusak Bentuk Remuk Sumber: Data diolah, 2017

Dapat dilihat dari Gambar 3. bahwa kerusakan bentuk remuk pada produk disebabkan oleh adonan pada saat dibentuk bulat tidak pas sehingga pada proses pencetakan kulit pie menjadi terlalu tipis, hal tersebut juga disebabkan karena proses pembuatan bulatan masih manual. Penempatan pie susu yang ditumpuk tumpuk karena tempat yang kurang luas sehingga pie susu mudah remuk. Peralatan yang kotor karena masih adanya sisa adonan dan kurang perawatan juga menjadi penyebab pie susu menjadi mudah remuk karena tekstur pie susu yang lengket akan menempel pada alat yang kotor tersebut. Faktor lingkungan yaitu karena tempat yang kurang luas, hal ini disebabkan karena penataan sarana dan 
prasarana produksi yang kurang rapid an kurang bersih. Faktor lainnya adalah karena pekerja yang kurang hati - hati. Kekurang hati - hatian pekerja karena disebabkan ruangan produksi yang panas, pekerja terburu - buru karena pekerjaan hampir selesai, serta pekerja ceroboh pada saat pemindahan loyang dari tempat proses pendinginan ke tempat untuk proses packaging.

Kerusakan kedua adalah karena warna gosong, kerusakan warna gosong disebabkan oleh faktor - faktor yang digambarkan pada diagram sebab akibat Gambar 4. sebagai berikut.

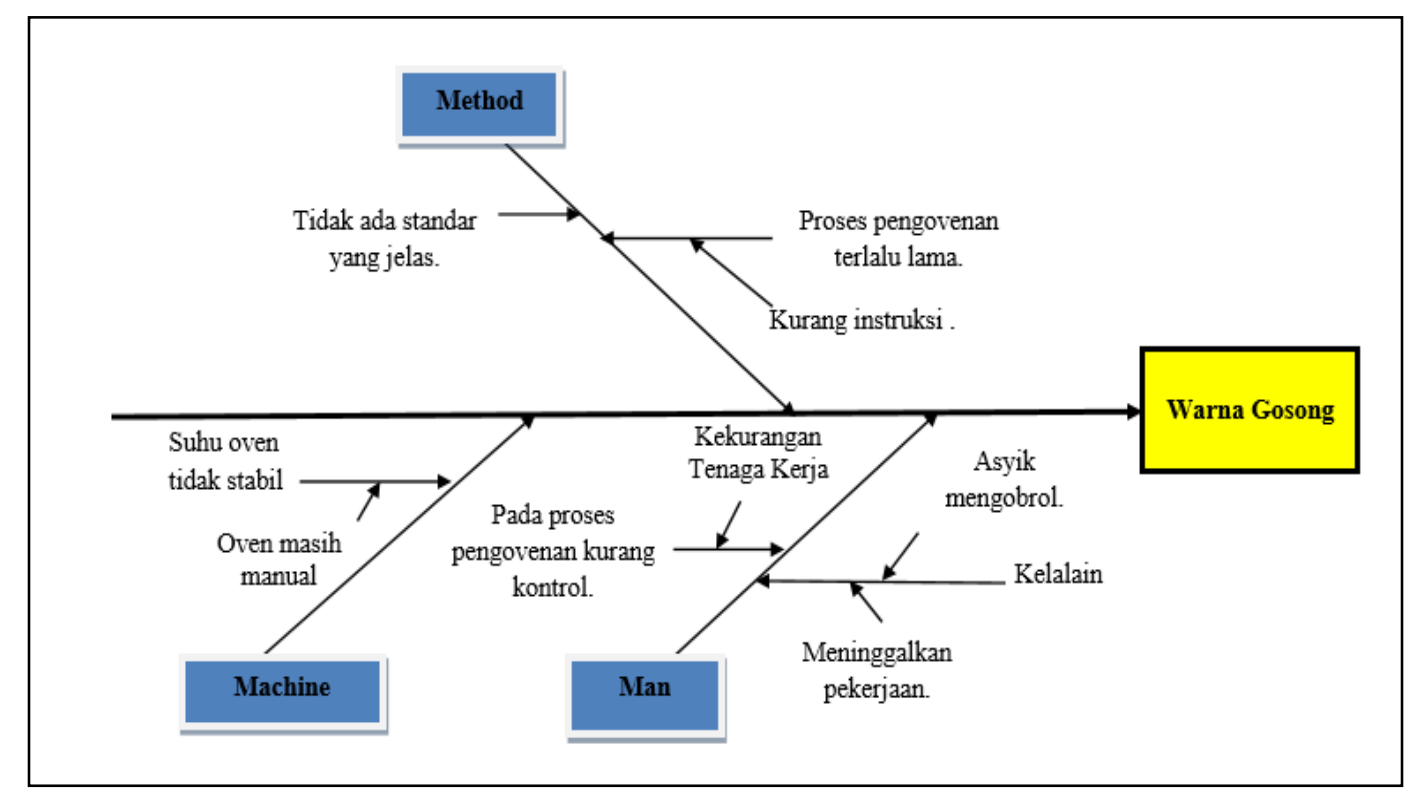

Gambar 4. Fishbone Diagram Produk Rusak Warna Gosong Sumber: Data diolah, 2017

Dapat dilihat dari Gambar 4. menunjukkan bahwa kerusakan warna gosong pada produk disebabkan proses pengovenan terlalu lama, hal ini disebabkan karena kurangnya instruksi dari bagian pengawas dan tidak ada standar waktu yang jelas dan setiap berapa kali untuk melakukan pengecekan pada proses pengovenan. Faktor lain karena suhu oven yang tidak stabil juga menyebabkan warna gosong pada pie susu, hal tersebut disebabkan karena mesin oven yang 
Ni Kadek Ratna Sari, Analisis Pengendalian Kualitas Proses Produksi Pie Susu...

digunakan masih manual menggunakan api dari kompor gas, sehingga jika pekerja lalai dalam mengecek suhu oven akan menyebabkan produk pie susu gosong. Pekerja yang lalai disebabkan karena pekerja meninggalkan pekerjaan untuk mengobrol sambil menunggu pie susu matang, sehingga pekerja tidak tepat waktu dalam mengontrol dan mengangkat pie susu yang telah matang. Kurangnya kontrol pada bagian pengovenan juga disebabkan karena kurangnya pekerja.

Kerusakan kedua adalah karena ukuran tidak sesuai, kerusakan warna gosong disebabkan oleh faktor - faktor yang digambarkan pada diagram sebab akibat Gambar 5. sebagai berikut.

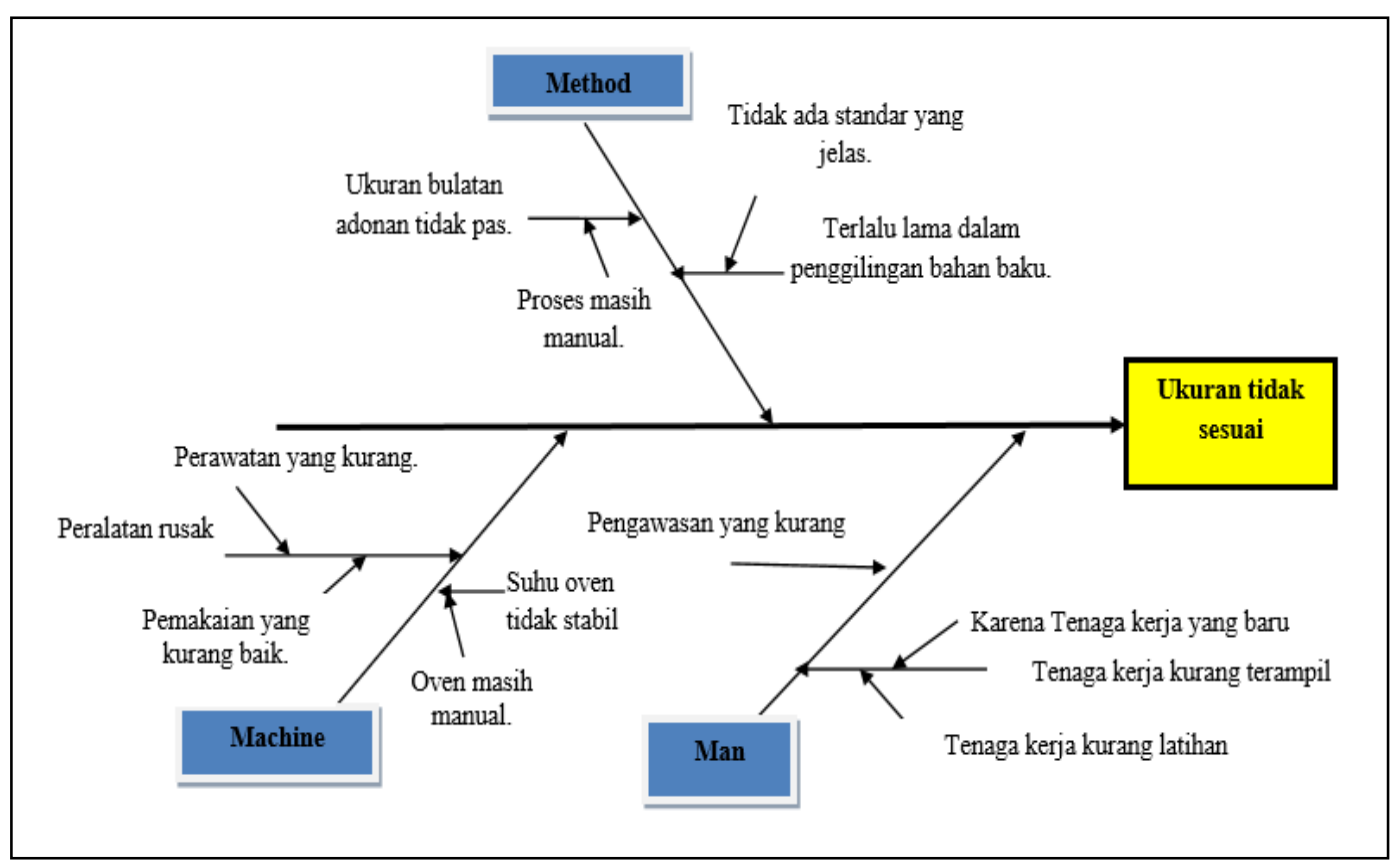

Gambar 5. Fishbone Diagram Produk Rusak Ukuran Tidak Sesuai Sumber: Data diolah, 2017

Dapat dilihat dari Gambar 5. bahwa kerusakan ukuran tidak sesuai disebabkan pada proses pembuatan bulatan adonan tidak pas, hal tersebut disebabkan karena proses pembuatannya masih manual yaitu menggunakan tangan, selain itu juga disebabkan karena proses penggilingan adonan yang terlalu 
lama sehingga membuat adonan akan menjadi terlalu mengembang dan memperbesar volume kulit pie dan isian vla hal tersebut disebabkan karena tidak ada standar waktu yang jelas dalam proses membuat adonan tersebut. Faktor penyebab yang lain yaitu karena peralatan yang rusak, hal tersebut dikarenakan pemakaian yang kurang baik dan tidak diganti, penyebab suhu oven yang tidak stabil juga memicu produk memiliki ukuran yang tidak sesuai. Faktor pekerja yang kurang terampil juga menjadi penyebab kerusakan ukuran tidak sesuai, hal tersebut disebabkan karena tenaga kerja yang masih baru dan kurang diberikan pelatihan, serta kurangnya pengawasan yang dilakukan.

Berdasarkan peta kendali $\mathrm{p}$, dapat dilihat bahwa pengawasan kualitas di Perusahaan Pie Susu Barong masih di batas kendali, namun untuk mengetahui apakah pengendalian kualitas yang dilakukan tersebut optimal atau tidak, maka perlu dilakukan analisis biaya kualitas. Terlebih dahulu ditentukan jumlah kerusakan produk terendah, kemudian dilanjutkan untuk mencari jumlah biaya pengawasan kualitas, biaya jaminan kualitas dan total biaya kualitas terendah sehingga bisa mencapai biaya kualitas yang optimum.

Biaya perawatan mesin terdiri dari:

$$
\begin{array}{ll}
\text { Penggantian piringan stamp kulit pie } & \text { Rp 250.000/bulan } \\
\text { Perawatan dan pengecekan mesin adonan } & \frac{\text { Rp 100.000/bulan }}{\text { Rp 350.000/bulan }}
\end{array}
$$

Biaya inspeksi proses produksi merupakan biaya yang dikeluarkan perusahaan untuk melakukan kegiatan pemeriksaan terhadap proses produksi dan kualitas produk selama proses produksi berlangsung. Inspeksi di perusahaan dilakukan oleh supervisor bagian produksi, sehingga biaya yang dikeluarkan 
Ni Kadek Ratna Sari, Analisis Pengendalian Kualitas Proses Produksi Pie Susu...

perusahaan berupa biaya gaji karyawan supervisor bagian produksi, yaitu sebesar Rp. 1.800.000/bulan.

Biaya jaminan kualitas merupakan biaya - biaya yang harus dikeluarkan oleh Perusahaan Pie Susu Barong untuk menanggung beban kerugian akibat kerusakan produk yang dihasilkan perusahaan. Besarnya biaya jaminan kualitas setiap biji pie susu yang ditanggung oleh perusahaan adalah sebesar harga jual rata - rata per biji pie susu yaitu sebesar Rp 1.200.

Untuk menghitung biaya kualitas aktual terlebih dahulu dilakukan perhitungan biaya pengawasan. Perhitungan biaya pengawasan terdiri dari: 1) Jumlah produksi selama satu tahun $(\mathrm{R})$ adalah $272.500 \times 12=3.270 .000$ pcs pie susu; 2) Biaya tenaga kerja pengawas kualitas Rp 1.800.000/bulan, maka selama satu tahun biayanya adalah sebesar: Rp $1.800 .000 \times 12 \times 1$ orang $=\operatorname{Rp} 21.600 .000$; 3) Biaya perawatan mesin $\operatorname{Rp} 350.000 /$ bulan $x 12=\operatorname{Rp} 4.200 .000$; 4) Kegiatan pengendalian kualitas dilakukan setiap hari kerja. Jumlah hari kerja normal selama satu bulan rata - rata sebanyak 25 hari, jadi jika dalam satu tahun maka kegiatan pengendalian kualitas dilakukan sebanyak 25 x $12=300$ kali. Sehingga didapatkan biaya pengetesan (o) adalah:

$$
\mathrm{O}=\frac{\operatorname{Rp} 21.600 .000+\operatorname{Rp} 4.200 .000}{300}=\operatorname{Rp} 86.000
$$

Sehingga, Biaya Pengawasan Kualitas (QCC)

$$
\begin{aligned}
\text { QCC } & =\frac{\text { R.o }}{q} \\
& =\frac{3.270 .000 \times \operatorname{Rp} 86.000}{7884}=\operatorname{Rp} 35.669 .710
\end{aligned}
$$


Biaya Jaminan Kualitas (QAC)

$$
\begin{aligned}
\mathrm{QAC} & =\mathrm{c} . \mathrm{q} \\
& =\mathrm{Rp} 1200 \times 7884 \\
& =\operatorname{Rp} 9.460 .800
\end{aligned}
$$

Total Biaya atas Kualitas (TQC)

$$
\begin{aligned}
\mathrm{TQC} & =\mathrm{QCC}+\mathrm{QAC} \\
& =\operatorname{Rp} 35.669 .710+\operatorname{Rp} 9.460 .800 \\
& =\operatorname{Rp} 45.130 .510
\end{aligned}
$$

Perhitungan Biaya Kualitas Optimal

Berdasarkan perhitungan biaya pengawasan kualitas, maka dapat ditentukan jumlah pie susu rusak yang menanggung biaya minimum $\left(\mathrm{q}^{*}\right)$ sebagai berikut:

$$
\begin{aligned}
\mathrm{q}^{*} & =\sqrt{\frac{\text { R.o }}{\mathrm{c}}} \\
& =\sqrt{\frac{3.270 .000 \times \mathrm{Rp} 86.000}{\operatorname{Rp} 1200}} \\
& =15.308 \text { biji pie susu }
\end{aligned}
$$

Sehingga, biaya kualitas yang ditanggung oleh Perusahaan Pie Susu Barong dengan jumlah kerusakan pie susu batas optimum adalah sebagai berikut:

Biaya Pengawasan Kualitas (QCC)

$$
\begin{aligned}
\text { QCC }^{*} & =\frac{\mathrm{R} \_o^{\mathrm{o}}}{\mathrm{q}} \\
& =\frac{3.270 .000 \times \operatorname{Rp} 86.000}{15.308} \\
& =\operatorname{Rp} 18.370 .786
\end{aligned}
$$


Ni Kadek Ratna Sari, Analisis Pengendalian Kualitas Proses Produksi Pie Susu...

Biaya Jaminan Kualitas (QAC)

$$
\begin{aligned}
\text { QAC* }^{*} & =\text { c.q } \\
& =\operatorname{Rp} 1200 \times 15.308 \\
& =\operatorname{Rp} 18.369 .600
\end{aligned}
$$

Total Biaya atas Kualitas (TQC)

$$
\begin{aligned}
\mathrm{TQC}^{*} & =\mathrm{QCC}^{*}+\mathrm{QAC}^{*} \\
& =\operatorname{Rp} 18.370 .786+\operatorname{Rp} 18.369 .600 \\
& =\operatorname{Rp} 36.740 .386
\end{aligned}
$$

Perhitungan jumlah kerusakan dan biaya - biaya atas kualitas aktual dan optimal telah dilakukan, maka selanjutnya dapat dilakukan perbandingan hasil biaya - biaya kualitas aktual perusahaan dengan biaya optimum yang seharusnya dikeluarkan oleh perusahaan, dapat dilihat pada Tabel 3.

Tabel 3.

Perbandingan Biaya Aktual Perusahaan dan Biaya Optimum di Perusahaan Pie Susu Barong

\begin{tabular}{cccc}
\hline Indikator & Aktual & Optimum & Selisih \\
\hline Jumlah Kerusakan (biji) & 7.884 & 15.308 & 7.424 \\
Biaya Pengawasan Kualitas (Rp) & 35.669 .710 & 18.370 .786 & 17.298 .924 \\
Biaya Jaminan Kualitas (Rp) & 9.460 .800 & 18.369 .600 & $8,908.600$ \\
\hline Total Biaya Kualitas (Rp) & 45.130 .510 & 36.740 .386 & 8.390 .124 \\
\hline
\end{tabular}

Sumber: Data diolah, 2017

Berdasarkan Tabel 3. dapat dilihat bahwa jumlah kerusakan aktual sebesar 7.884 biji pie susu lebih kecil dibandingkan jumlah batas kerusakan biaya optimal yaitu sebesar 15.345 biji pie susu, namun total biaya kualitas sebesar Rp 45.130.510 lebih besar dibandingkan biaya kualitas optimum sebesar Rp 36.740.386, hal ini disebabkan karena biaya pengawasan kualitas aktual yang 
tinggi sebesar Rp 35.669.710 dibandingkan biaya pengawasan optimum sebesar Rp 18.370.786, sedangkan biaya jaminan mutu aktual sebesar Rp 9.460.800 lebih kecil dibandingkan biaya jaminan mutu optimum sebesar Rp 18.369.600. Selisih antara total biaya kualitas aktual dengan total biaya kualitas optimum sebesar Rp 8.390.124 menunjukkan belum optimalnya pengendalian kualitas yang dilakukan perusahaan, karena terlalu tinggi mengeluarkan biaya pengawasan kualitas sehingga dapat mengurangi keuntungan yang diperoleh perusahaan.

Berdasarkan data pada Tabel 3., maka dapat dibuat grafik mengenai biaya total kualitas dan tingkat kerusakan produk pie susu yang dibebankan oleh perusahaan adalah sebagai berikut.

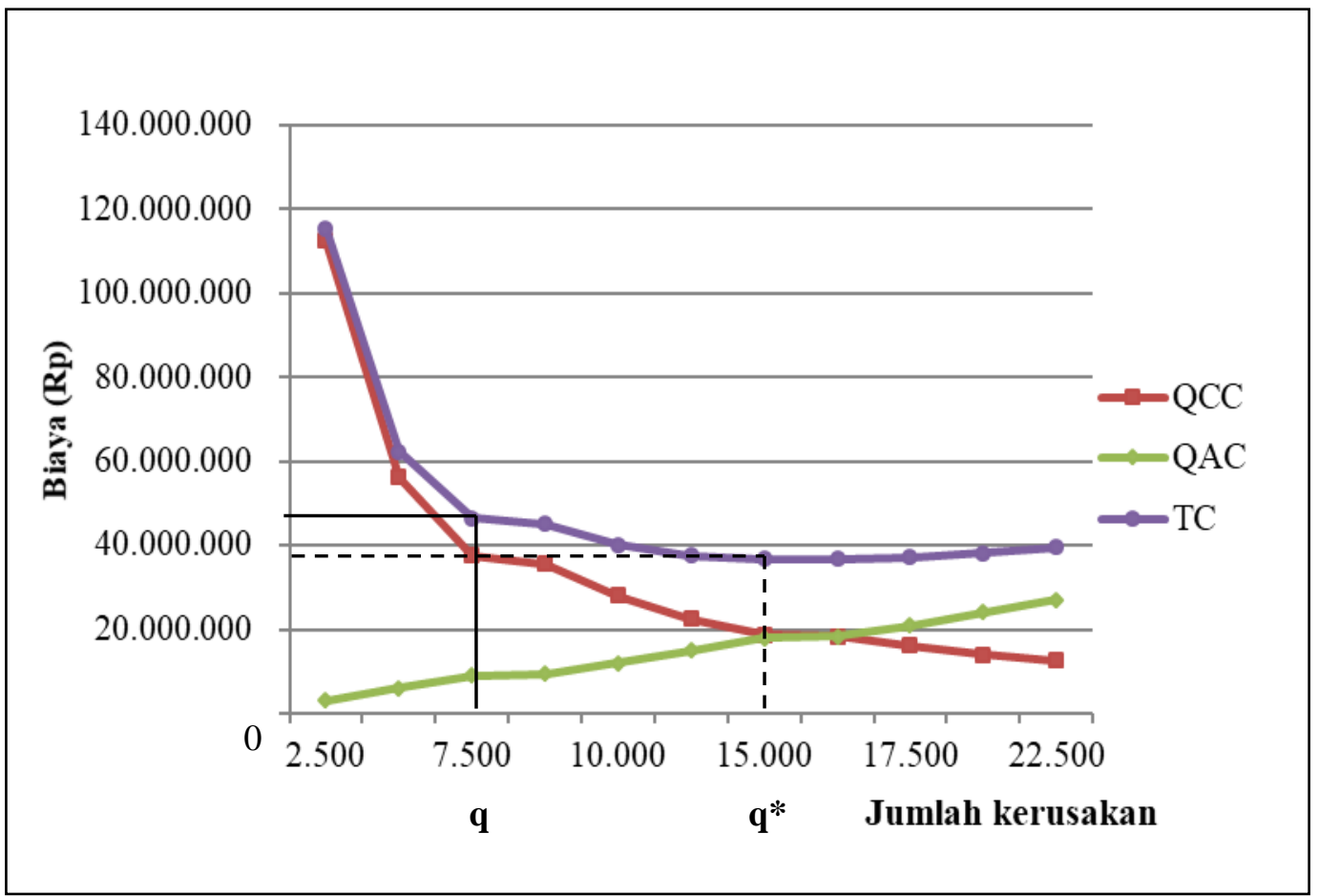

Gambar 6. Biaya Kualitas Produk Pie Susu Perusahaan Pie Susu Barong Sumber: Data diolah, 2017

Gambar 6. menunjukkan bahwa selama periode 2017 jumlah kerusakan produk pada Perusahaan Pie Susu Barong adalah sebesar 7.884 biji pie susu, maka 
Ni Kadek Ratna Sari, Analisis Pengendalian Kualitas Proses Produksi Pie Susu...

biaya aktual yang dikeluarkan perusahaan terdiri dari biaya pengawasan mutu (QCC) sebesar Rp 35.669.710 dan biaya jaminan mutu (QAC) sebesar Rp 9.460.800 sehingga untuk total biaya kualitas (TQC) adalah sebesar Rp 45.130.510. Titik terendah atau titik optimal biaya kualitas yaitu berada pada batas kerusakan sebesar 15.308 biji pie susu dengan total biaya kualitas (TQC) optimum sebesar Rp 36.740.386 yang terdiri dari biaya pengawasan kualitas (QCC) sebesar Rp 18.370.786 dan biaya jaminan mutu (QAC) sebesar Rp 18.369.600. Maka, dapat disimpulkan bahwa pengawasan yang dilakukan perusahaan sudah sangat ketat, namun pengendalian kualitas yang dilakukan belum optimal karena total biaya kualitas aktual lebih besar dibandingkan total biaya kualitas optimumnya, di mana selisih biaya total kualitas aktual dengan total biaya kualitas optimum adalah sebesar Rp 8.390.124 atau perusahaan seharusnya dapat mengefesienkan biaya sebesar $18 \%$ dari total biaya kerusakan aktual.

Sutrisno (2012) juga menyatakan bahwa antara QCC dan jumlah kerusakan memiliki hubungan negatif, yaitu QCC akan meningkat apabila jumlah produk rusak menurun begitu pula sebaliknya QCC akan menurun apabila jumlah produk rusak meningkat. Berbeda dengan hubungan antara QAC dan jumlah kerusakan yang memiliki hubungan yang positif, di mana QAC akan meningkat apabila jumlah produk yang rusak juga meningkat, sebaliknya QAC akan menurun apabila jumlah produk rusak menurun.

Langkah selanjutnya apabila penyebab kerusakan sudah diketahui, maka dapat disusun suatu usulan tindakan perbaikan secara umum dalam upaya menekan tingkat kerusakan produk. Adapun perbaikan yang dilakukan untuk 
mengurangi kerusakan produk yang disebabkan oleh faktor manusia, yaitu a) Melakukan briefing secara rutin tentang instruksi kerja sebelum proses produksi dimulai; b) Memasang peraturan, larang - larangan serta sanksi di tempat produksi agar karyawan lebih disiplin dan hati - hati dalam bekerja; c) Menanamkan rasa peduli terhadap lingkungan kerja, peralatan produksi dan bahan baku pada setiap karyawan untuk tetap menjaga kualitas produk yang dihasilkan; d) Memberikan waktu istirahat yang jelas kepada setiap karyawan, misalnya dalam hal ini yaitu mengatur jadwal dan batas waktu istirahat mereka agar karyawan lebih optimal dalam bekerja dan proses produksi dapat berjalan dengan lancer; e) Menganalisa dan mendokumentasikan suatu produk rusak, penyebabnya, cara penanggulangannya dan masalah-masalah lainnya pada proses guna dilakukan tindakan perbaikan sehingga masalah tersebut dapat dicegah agar tidak terulang kembali; f) Perusahaan perlu mengadakan pelatihan untuk meningkatkan keterampilan karyawan terutama bagi karyawan baru secara kontinu agar dapat tercapai sumber daya manusia yang berkualitas; g) Memberikan layanan yang ramah dan jaminan kualitas terhadap produk yang dibeli oleh konsumen, agar konsumen tetap setia dan merasa aman untuk mengonsumsi produknya; dan h) Membentuk tim pengawas untuk mengawasi dan mengecek ulang kinerja pekerja agar dapat mengurangi kesalahan yang disebabkan oleh human error.

Selain faktor manusia, perbaikan kualitas juga dilakukan pada penyebab faktor metodenya, diantaranya adalah: a) Memberikan instruksi kerja dengan jelas kepada karyawan, hal ini bisa dilakukan pada saat awal sebelum proses produksi 
Ni Kadek Ratna Sari, Analisis Pengendalian Kualitas Proses Produksi Pie Susu...

dimulai ataupun pada saat proses produksi berlangsung; b) Membuat SOP yang jelas dan menempatkan pada lokasi yang mudah dibaca di area proses produksi agar pekerja produksi selalu senantiasa mengikuti dan mengingat SOP yang telah dibuat; c) Memasang papan atau dokumen khusus yang menggambarkan tingkat perubahan jumlah produk rusak per harinya dengan grafik sehingga tenaga pengawas bisa mengetahui dengan mudah. Atau laporan khusus untuk bagian produksi yang melakukan kesalahan per harinya, sehingga pada bagian produksi mengetahui tingkat ketelitian yang mereka lakukan; d) Membuat standar waktu untuk melakukan controlling terutama pada proses pengovenan dan proses penggilingan adonan agar kerusakan pie susu karena warna gosong dan ukuran tidak sesuai dapat ditekan; e) Menjaga kerapian dan kebersihan lingkungan pabrik agar tersedia space yang luas untuk menaruh pie susu.

Kerusakan juga disebabka karena adanya faktor mesin, sehingga tindakan perbaikan kualitas yang dapat dilakukan adalah sebagai berikut: a) Pemeriksaan mesin -mesin tidak hanya dilakukan ketika mesin mengalami kerusakan, namun harus dilakukan secara rutin atau secara berkala; b) Apabila hendak mengoperasikan mesin harus dipastikan tidak ada benda yang dapat mengganggu kinerja mesin untuk mencegah kerusakan dan mengoptimalkan kinerja mesin, kondisi mesin ataupun peralatan harus selalu dalam keadaan bersih; c) Membersihkan alat - alat yang kotor secara teliti agar tidak ada sisa adonan yang menempel.

Tindakan perbaikan kualitas yang disebabkan oleh faktor lingkungan dapat dilakukan dengan melakukan penataan alat - alat produksi agar lebih rapi dan 
bersih, sehingga tersedia tempat yang lebih luas untuk meletakkan hasil produksi selain itu karyawan lebih nyaman dalam bekerja.

\section{SIMPULAN DAN SARAN}

Berdasarkan hasil penelitian yang dilakukan dapat disimpulkan bahwa pengendalian kualitas yang dilakukan di Perusahaan Pie Susu Barong masih belum optimal karena hasil analisis biaya kualitas produksi periode 2017 menunjukkan biaya kualitas untuk kerusakan aktual lebih besar dari biaya kualitas optimal. Kerusakan aktual sebesar 7.884 biji pie susu, biaya pengawasan mutu (QCC) yang dikeluarkan sebesar Rp 35.669.710 dan biaya jaminan mutu (QAC) sebesar Rp 9.460.800 sehingga untuk total biaya kualitas (TQC) aktual adalah sebesar Rp 45.130.510. Sedangkan, pada batas kerusakan sebesar 15.308 biji pie susu, total biaya kualitas (TQC) optimum adalah sebesar Rp 36.740.386 yang terdiri dari biaya pengawasan kualitas (QCC) sebesar Rp 18.370.786 dan biaya jaminan mutu (QAC) sebesar Rp 18.369.600.

Saran yang diberikan adalah perusahaan perlu mengantisipasi faktor - faktor penyebab terjadinya produk rusak dan kegiatan produksi dapat dilakukan dengan lebih optimal, adapun saran untuk mengantisipasi empat faktor penyebab kerusakan adalah sebagai berikut: 1) Man (Manusia), yaitu perusahaan perlu mengadakan pelatihan untuk meningkatkan keterampilan karyawan terutama bagi karyawan baru secara kontinu agar dapat tercapai sumber daya manusia yang berkualitas; 2) Method (Metode), yaitu memberikan instruksi kerja dengan jelas kepada karyawan, hal ini bisa dilakukan pada saat awal sebelum proses produksi dimulai ataupun pada saat proses produksi berlangsung. 3) Machine (Mesin), 
yaitu memeriksa mesin -mesin tidak hanya dilakukan ketika mesin mengalami kerusakan, namun harus dilakukan secara rutin atau secara berkala. 4) Environment (Lingkungan), yaitu melakukan penataan alat - alat produksi agar lebih rapi dan bersih, sehingga tersedia tempat yang lebih luas untuk meletakkan hasil produksi selain itu karyawan lebih nyaman dalam bekerja.

\section{REFRENSI}

Assauri, Sofjan. 2004. Manajemen Pemasaran. Jakarta: Rajawali Press.

Ayu Ningsih, Ni K., I Ketut Suamba, dan I.D.G. Raka Sarjana. 2016. Pengawasan Mutu pada Pengolahan Dodol Salak di CV Duta Gunung Salak. E-Jurnal Agribisnis dan Agrowisata, 5 (2) : 399-407.

Bakhtiar, S., Tahir, Suharto dan Hasni, Ria Asysyfa. 2013. Analisa Pengendalian Kualitas Dengan Menggunakan Metode Statistical Quality Control (SQC) Studi Kasus: pada UD. Mestika Tapaktuan. Malikussaleh Industrial Engineering Journal, 2 (1) : 29-36.

Bambharoliya, S.H., and Thakkar, H. R. 2015. Reducing Rejection Rate in Small Scale Machining Unit Using 7 Quality Control Tools - A Review. International Journal of Engineering Development and Research, 3(4) : $582-586$.

Banker, Kapil., Patel, Amit., and Patel, Diptesh. 2014. Implementation of Statistical Quality Control (S.Q.C.) in Welded Stainless Steel Pipe Manufacturing Industry. International Journal of Research in Engineering and Technology, 3 (9) : 270 - 273.

Bose, Tarun Kanti. 2012. Application of Fishbone Analysis for Evaluating Supply Chain and Business Process - A Case Study on the St James Hospital. International Journal of Managing Value and Supply Chains (IJMVSC), $3(2): 17-24$.

Darsono. 2013. Analisis Pengendalian Kualitas Produksi dalam Upaya Mengendalikan Tingkat Kerusakan Produk. Jurnal Ekonomi Manajemen Akuntansi, 20 (35).

Elmas, Muhammad Syarif H. 2017. Pengendalian Kualitas dengan Menggunakan Metode Statistical Quality Control (SQC) Untuk Meminimumkan 
Produk Gagal Pada Toko Roti Barokah Bakery. Jurnal Penelitian Ilmu Ekonomi WIGA, Vol. 7: 15-22.

Hariastuti, Ni Luh Putu. 2015. Analisis Pengendalian Mutu Produk Guna Meminimalisasi Produk Cacat. Jurnal Seminar Nasional IENACO, IENACO, ISSN:2337-4349: 268 - 275.

Hariyanto, Agus.M. 2017. Pengendalian Kualitas Produk Roti Tawar "Della" Menggunakan Metode Statistical Process Control. Simki - Economic, $1(5): 1-15$.

Haslindah, A. 2013. Analisa Pengendalian Mutu Minuman Rumput Laut dengan Menggunakan Metode Statistical Quality Control pada PT. Jasuda di Kabupaten Takalar. Jurnal ILTEK, 8 (15) : 1090 -1094

Heizer, Jay and Render, Barry. 2006. Manajemen Operasi. Jakarta: Salemba Empat.

-------. 2009. Buku 1 Edisi 9. Manajemen Operasi. Jakarta: Salemba Empat.

Jha, Mayank., Tyagi, R.K, and Gupta, Gaurav. 2013. Reduction of Rejected Components in an Automobile Assembly Line Using Quality Tools. European Journal of Applied Engineering and Scientific Research, 2 (3), pp.13 - 17.

Mahesh, B.P. and Prabhuswamy, M.S. 2010. Process Variability Reduction Through Statistical Process Control for Quality Improvement. International Journal for Quality Research, 4(3) : 193-203.

Mostafaeipour, A., Sedaghat, A., Hazrati, A., and Vahdatzad M. 2012. The use of Statistical Process Control Technique in the Ceramic Tile Manufacturing: a Case Study. International Journal of Applied Information Systems , 2 (5) : 14 -19.

Mulyadi. 2014. Akuntansi Biaya. Edisi 5. Yogyakarta: STIM-YKPN.

Neyestani, Behnam. 2017. Seven Basic Tools of Quality Control: The Appropriate Techniques for Solving Quality Problems in the Organizations. https://mpra.ub.uni-muenchen.de/77941/. Diakses 1 Desember 2017.

Oguntunde, P.E., Odetunmibi, O.A., and Oluwadare, O.O. 2015. A Comparative Study of the Use of Statistical Process Control in Monitoring Health Care Delivery. International Journal of Innovation and Scientific Research, 14 (2) : $154-158$.

Patil, Pipik and Sutar, Mahesh. 2015. Quality control and Statistical Techniques used to improve Productivity and to reduce Rejections due to Casting 
Ni Kadek Ratna Sari, Analisis Pengendalian Kualitas Proses Produksi Pie Susu...

Defects: A Review. International Journal of Research in Advent Technology, 3 (4) :71 - 78.

Phillips J and Simmonds L. 2013. Change Management Tools Part 1: Using Fishbone Analysis to Investigate Problems. Nursing Times, 109 (15) : $18-20$

Prihatiningtias, Inah., Hadi Wahyono dan Didik Pudjo M. 2014. Analisis Pengendalian Kualitas Produk Paving Block menggunakan Statistical Quality Control pada CV. Multi Bangunan Jember. http.//repository.unej.ac.id/handle/123456789/58475. Diakses 22 September 2017.

Putra, Hendi Pramana. 2016. Analisis Pengendalian Kualitas Produk Genteng Beton pada CV. Multi Bangunan Jember. Skripsi Sarjana Jurusan Manajemen pada Fakultas Ekonomi Universitas Jember.

Ransun, Kristina, M., Saerang, D.P.E., dan Warongan, J.D.L. 2016. Pengaruh Biaya Kualitas dan Biaya Produksi terhadap Peningkatan Kualitas Produk pada Trinity Percetakan Manado. Jurnal Berkala Ilmiah Efisiens, $16(4): 79-90$.

Sutrisno, Badri Romadhon. 2012. Pengendalian Kualitas Produk Dengan Pendekatan Model SQC (Statistikal Quality Control) Aplikasi model pada Perusahaan Furniture. Universitas Widya Dharma Klaten. http//journal.unwidha.ac.id. Diakses 22 September 2017.

Wahyuni, Sry. 2016. Analisis Biaya Kualitas untuk Mengurangi Produk Cacat pada PT. Fajar Utama Intermedia. Skripsi Sarjana Jurusan Akuntansi pada Fakultas Ekonomi Halu Oleo Kendari.

Yuliasih, Ni Kadek. 2014. Analisis Pengendalian Kualitas Produk pada Perusahaan Garmen Wana Sari Tahun 2013. E-journal Undiksha, 4(1) : $1-12$.

Yuliyarto dan Putra, Yanuar Surya. 2014. Analisis Quality Control pada Produksi Susu Sapi di CV Cita Nasional Getasan Tahun 2014. Jurnal STIE AMA Salatiga, 7 (14) : 79 -91. 